\title{
Mini-Review of Analytical Methods used in Quantification of Ellagic Acid
}

https://doi.org/10.1515/revac-2020-0113

Received February 16, 2020; accepted June 16, 2020

\begin{abstract}
Ellagic acid is an important phytochemical present in different plants such as Strawberry, Grapes, Blackberry, Raspberry etc. Chemically, ellagic acid is 2, 3, 7, 8-tetrahydroxychromeno [5, 4, 3-cde] chromene-5, 10-dione. It is an organic heterotetracyclic compound resulting from the dimerization of gallic acid molecules by oxidative aromatic coupling with intramolecular lactonization. Ellagic acid has been reported for various pharmacological activities such as anti-inflammatory, neuroprotective, cardioprotective, antioxidant, antimutagenic etc. Various analytical methods based on spectrophotometry, chromatography, hyphenated techniques, capillary zone electrophoresis etc. have been developed for identification and quantification of ellagic acid in natural sources and formulations. The present review provides detailed information on quantitative analysis of ellagic acid present in Strawberry, Grapes, Blackberry, Raspberry, Cranberry; Syzygium cumini seed extract, Woodfordia fruticosa plant extract, Potentilla species extracts etc. It also focuses on analytical methods for quantification of ellagic acid in herbal and traditional formulations such as Ashwagandharishta, Triphala churna, Dhatrinisha churna, Arjunarishta, Manjisthadi churna.
\end{abstract}

Key Words: Ellagic acid, polyphenols, analytical methods, extracts, formulations, HPLC, HPTLC

\section{Introduction}

Tannins are phenolic compounds found in different plants. They precipitate proteins and also form complex

\footnotetext{
*Corresponding author: yogeshkulkarni101@yahoo.com

${ }^{1}$ Shobhaben Pratapbhai Patel School of Pharmacy \& Technology Management, SVKM's NMIMS, V.L. Mehta Road, Vile Parle (W), Mumbai - 400 056, India.

${ }^{2}$ Vivekanand Education Society's College of Pharmacy, Chembur (East), University of Mumbai, Mumbai 400 074, India.
}

with minerals, starch and cellulose. Tannins are usually divided into two groups: hydrolysable tannins and condensed tannins. Hydrolysable tannins include gallotannins and ellagitannins. These are usually present in small amounts in plants. These phytoconstituents are environmentally very important because they are easily water soluble at most pH's and they tend to combine with toxic metal ions which may reduces bioavailability.

Depending upon nature of phenolic acid, hydrolysable tanninsare divided into two subclasses namely gallotannins and ellagitannins [3]. Gallotannins show presence of gallic acid whereas ellagitannins show presence of ellagic acid [4]. Upon hydrolysis of gallotannins yields sugar and gallic acid, while ellagitannins contain hexahydroxydiphenic acids that produce ellagic acid after hydrolysis $[5,6]$.

Different pharmacological activities of ellagic acid have been reported such as antioxidant [7,8,9], antimalarial [10], anti-inflammatory [11], antihepatotoxic [12], antiproliferative [9,13,14], anticholestatic [15,16], antifibrogenic [12], antihepatocarcinogenic [18,21] and antiviral [20-22]. Ellagic acid has also been reported for its potential neuroprotective action [23]. It has also shown significant effects in management of metabolic syndrome [24]. Ellagic acid is having cytotoxic, antitumor, and anticancer effects [25]. It has also been reported for its cardioprotective effects [26,27] and used as an anti tubercular agent [28]. Ellagic acid also improves the hepatic architectural and functions against toxic and pathological conditions [15]. Derivatives of ellagic acid like urolithins and 4,4' -Di -O-methyl ellagic acid have been reported to inhibit colon cancer cell proliferation [29]. Moreover, ellagic acid has been reported to block activated pancreatic stellate cells [30]. Ellagic acid also has apoptosis inducing activities [31]. UV radiation causes oxidative stress through production of ROS, which disrupt the endogenous antioxidative system of the skin cells and may lead to skin inflammatory disorders, depigmentation, photo aging, and carcinoma. Ellagic acid has shown protective effects in these conditions $[32,33]$. The intake of ellagic acid varies in humans around the world and depends on both the region and the life-style. It can usually be obtained directly in its free form or as ellagitannins, which are hydrolyzed by the enzyme ellagitannase (ellagitannin acyl hydrolase) to release 
ellagic acid and other relevant metabolites [34]. Biochemical and physiological actions of ellagic acid includes inhibition of glutathione S-transferase, contact activation in blood coagulation. It is also used for the assay of factor XIIa in plasma [35]. Ellagic acid is present in Strawberry [2], Grapes [36], Blackberry [1], Raspberry [2], Cranberry [37], Pomegranate [38,39], Guava [40], Walnuts [41,39] and Blueberry [2].

To know various physicochemical properties of natural products different analytical instruments are used. The very basic and important is UV Vis Spectrophotometer to measure the maximum absorbance of the compound. UV-visible spectroscopy (radiations with wavelengths between 10 and $1000 \mathrm{~nm}$ ) offers information about the transition of the most external electrons of the atoms. UV-visible spectroscopy can be used to determine many physicochemical characteristics of compounds and thus can provide information to identify a particular compound [42].

One of the important biophysical techniques that enables us the separation, identification and purification of the phytoconstituent is chromatography. It is used for quantitative and qualitative analysis. It separates a mixture of phytoconstituents into their different components on the basis of their molecular structure and molecular composition involving a stationary phase and a mobile phase [42]. Herbal medicinal products and dietary supplements and now it become part of life that people take to improve their health. It is very essential to develop authentic analytical methods for these supplements which can reliably estimate the phyto-chemical composition, including quantitative analyses of bioactive compounds and other major phytoconstituents [43].

High-performance thin layer chromatography (HPTLC) is one of the sophisticated instrumental techniques for qualitative and quantitative analysis of the herbs and herbal drugs. HPTLC has a highly sensitive scanning densitometry for the rapid identification and quantification of phytoconstituents [46]. The HPTLC fingerprint is also suitable for rapid and simple authentication and comparison of the subtle differences among samples with identical plant sources but different geographic locations and hence is a very important tool in the herbal drug industry [43,44].

To investigate large numbers of plant secondary metabolites, it is important to have some strong rugged and robust technique which can analyze a number of samples without deviation from the results. All of these things can be achieved correctly by High-Performance Liquid Chromatography (HPLC) analysis, which is an extremely versatile technique [45]. The reversed-phase method is capable to handle compounds of a different molecular mass and having diverse polarity. RP-HPLC has got analytical and preparative application in the area of purification and separation of phytoconstituents [46,47].

Hyphenated techniques also have a unique application in the natural product analysis [48]. Current advancements in hyphenated analytical techniques have remarkably widened applications of LC-MS, GC-MS, LC-NMR, LC-PDA, LC-FTIR, LC-NMR-MS and CE-MS to the analysis of complex biomaterials, especially natural products [48]. Considering all the facts and facets, this review article mainly focuses on the different analytical techniques or methods available for quantification of the ellagic acid.

\section{Chemistry, Properties and biogenesis}

Ellagic acid belongs to the class of hydrolysable tannins. Its molecular weight is $302.194 \mathrm{~g} / \mathrm{mol}$ and molecular formula is $\mathrm{C}_{14} \mathrm{H}_{6} \mathrm{O}_{8^{2}}$. The reported melting point of ellagic acid is $350^{\circ} \mathrm{C}$ [20]. It is highly thermostable due to presence of four rings in the structure which represent lipophilic dominance, and the four phenolic groups and the two lactones representing the hydrophilic zone [49] (Figure 1). Ellagic acid is an organic heterotetracyclic compound resulting from the dimerization of Gallic acid by oxidative aromatic coupling with intramolecular lactonisation of both carboxylic acid groups of the resulting biaryl. It is a cyclic ketone, also a lactone, also a member of catechols and a polyphenol [50]. Ellagic acid appears as cream-colored needles (from Pyridine) or yellow powder, odorless powder. It is slightly soluble in alcohol or water, soluble in alkalies, in pyridine. It is practically insoluble in ether. When heated to decomposition it emits acrid smoke and irritating vapors [51]. Ellagitannins are found naturally in plants and vegetables as hexahydroxydiphenoylglucose esters, ingestion of these results in hydrolysis which releases ellagic acid which is weakly absorbed in the small intestine and stomach [29].<smiles>CCC(=O)c1cc(O)c(O)c(O)c1-c1c(C(=O)C(C)C)cc(O)c(O)c1O</smiles>

Figure 1 Structure of Hexahydroxidiphenic Group of Ellagitanins 
Plants phenols are mostly produced from the phenylpropanoid and shikimate pathway [52]. Ellagic acid is a polyphenolic compound obtained commercially by chemical extraction of plant materials mentioned in the source with the mixture of acid-methanol as solvents and hydrolysis with concentrated $\mathrm{HCl}$ or $\mathrm{H}_{2} \mathrm{SO}_{4}[12,20]$.

Ellagitannins are produced from gallotannins by oxidative interaction with minimum two galoyl units, which originates from hexahydroxydiphenic acid (HHDP). After hydrolysis of ellagitannins, this group will release and impetuously rearranged or lactonised to form the ellagic acid [53] (Figure 2). Aguilera-Carbo and co-workers in 2007 reported production of ellagic acid by fungal solid state culture using polyurethane foam (PUF) as support from an aqueous extract obtained from pomegranate husk (Punica granatum) [54]. It is combustible and incompatible with strong oxidizing agents.<smiles></smiles>

Figure 2 Structure of Ellagic acid

\section{Analytical Methods}

Analytical studies of herbal drugs and formulations are essential to get quantitative data for the presence of active constituents. To obtain the analytical data various instrumental techniques like spectroscopy, chromatography, electrophoresis, thermal methods, chemiluminescence and hyphenated techniques are widely used. Out of all these techniques, a few of the most versatile techniques are discussed for quantification of ellagic acid from different natural sources and formulations.

\subsection{Spectrophotometry}

Ultra Violet Spectrophotometry is a method used to measure absorbance of light by measuring the intensity of light passing through the chemical substance. Scientists from different backgrounds use this method as a basic and starting point of research. This data gives a basic idea about solubility and absorption profile of chemical.

Ellagic acid offers maximum absorption of (ethanol) 366, $255 \mathrm{~nm}$ with $\log \varepsilon$ 3.93, 4.60 (Pubchem, 2019). Considering the complex nature and structure of ellagic acid, Chen Jia-hong and co-researchers have made an attempt to dissolve the ellagic acid in dilute $\mathrm{NaOH}$ solution, as it wasn't dissolving in any of the organic solvents and in water. They have reported UV characteristic absorption peak of ellagic acid at $357 \mathrm{~nm}$ [55]. Budavari and co-researchers have reported $357 \mathrm{~nm}$ as a maximum absorption peak in UV region. They also reported that, ellagic acid is sparingly soluble in alcohol and insoluble in water [56]. Bala and co-investigators have determined the solubility of ellagic acid in water and methanol by using the validated UV spectroscopic method and they have reported maximum absorption at $255 \mathrm{~nm}$ and $360 \mathrm{~nm}$ [49] (Table 1). Maximum absorptions of ellagic acid have been reported at $255 \mathrm{~nm}, 254 \mathrm{~nm}$ and 360-368 $\mathrm{nm}$ in UV spectroscopic analyses [57,58].

Ellagic acid is a weakly acidic drug which shows an increase in solubility with $\mathrm{pH}$ and having reported $\mathrm{pKa}$ value of 5.6 [59]. It has four phenolic groups which are weak in acidic nature and should exhibits four dissociation constants [60,61]. Below a pH 5.6, ellagic acid exists in a mono-deprotonated form whereas, at a $\mathrm{pH}$ higher than 5.6, deprotonationoccursatthetwohydroxylgrouppositions [59]. Also the report showed that, solubility of ellagic acid increases after it has lost two hydrogen's per molecule. Attempts to increase the solubility of EA by increasing the $\mathrm{pH}$ resulted in development of dark greenish brown color, which could be due to the hydrolysis of lactone moieties $\left(\mathrm{pH} 9.6,10^{-5} \mathrm{M} \mathrm{NaOH}\right)[59,49]$.

In IR Spectroscopy, ellagic acid presents specific regions of absorption. Analysis of total polyphenols by IR spectrum was done by Goriparti and fellow researcher after

Table 1 Lambda Max of ellagic acid with different solvent systems by UV Spectrophotometry

\begin{tabular}{|l|l|l|l|}
\hline Compound & Solubility & Lambda Max & Reference \\
\hline Ellagic Acid & Ethanol & $366 \mathrm{~nm}$ & {$[50]$} \\
\hline Ellagic Acid & Dil. $\mathrm{NaOH}$ & $357 \mathrm{~nm}$ & {$[55]$} \\
\hline Ellagic Acid & Methanol & $255 \mathrm{~nm}$ and 360 nm & {$[49]$} \\
\hline Ellagic Acid & $100 \%$ methanol & $255 \mathrm{~nm}$ & {$[57]$} \\
\hline Ellagic Acid & $70 \%$ acetone in water $(\mathrm{v} / \mathrm{v})$ & 254 and 360-368 nm & {$[58]$} \\
\hline
\end{tabular}


scanning between 4000 to $10,000 \mathrm{~cm}^{-1}$ they have reported, the IR spectrum of the compound exhibits - $\mathrm{OH}$ broad band's stretching in the range, $2800-3700 \mathrm{~cm}^{-1}$, also at $1725 \mathrm{~cm}^{-1} \mathrm{C}=0$ stretching. An aromatic ring vibration band was observed in between, $1669-1500 \mathrm{~cm}^{-1}$. The one which is at 1190 and 1052 $\mathrm{cm}^{-1}$ are due to ester linkage. Another signal at $751 \mathrm{~cm}^{-1}$ has been assigned to aromatic $\mathrm{C}-\mathrm{H}$ bending vibration [62].

\subsection{Chromatography}

Various chromatographic methods have been reported for the identification/quantification of ellagic acid in extracts and in formulations.

\subsubsection{High Pressure Thin Layer Chromatography (HPTLC)}

High Performance Thin Layer Chromatography is a sophisticated and automated form of thin-layer chromatography [44], along with better and higher detection and separation capability [63]. The main application of this technique in the analysis of phytochemicals [64], quantification of phytochemicals [65], fingerprinting of formulations [44] and also it has wide role in checking the quality of formulations [66].

\subsubsection{HPTLC Analysis of Extracts}

Syzygium cumini seed extract was studied by Dalavi and group to analyze effect of ellagic acid for antibacterial activity. They have performed HPTLC study to determine the effect of accelerated storage on extract and markers of plant on the antibacterial activity after a six month study. The peak for ellagic acid was observed at $R_{f}$ of $0.47 \pm 0.02$. The results suggest that, the reduction in the antibacterial potential of the extract along with the concomitant reduction in the percentage assay over a six month study [67]. The details related to the parameters of the method are mentioned in the table 2.

Table 2 Quantitative analysis of ellagic acid by HPTLC methods

\begin{tabular}{|c|c|c|c|c|c|c|}
\hline Sample & Matrix & $\begin{array}{l}\text { extraction } \\
\text { element }\end{array}$ & $\begin{array}{l}\text { Chromatographic } \\
\text { conditions }\end{array}$ & Detection & $\begin{array}{l}\text { RT } \\
\text { (in Min) }\end{array}$ & Reference \\
\hline \multicolumn{7}{|l|}{ HPTLC Analysis of Extract: } \\
\hline Syzygium cumini seed & Extraction & Ethanol & $\begin{array}{l}\text { toluene: ethyl acetate: } \\
\text { formic acid }(6: 6: 1.5 \mathrm{v} / \mathrm{v} / \mathrm{v})\end{array}$ & $271 \mathrm{~nm}$ & $\begin{array}{l}0.47 \\
\pm 0.02\end{array}$ & {$[67]$} \\
\hline $\begin{array}{l}\text { Abrus precatorius, Phyllanthus } \\
\text { maderaspatensis, Nymphaea } \\
\text { alba Linn }\end{array}$ & Extraction & Methanol & $\begin{array}{l}\text { Toluene: ethyl acetate: } \\
\text { formic acid: methanol } \\
(3: 3: 0.8: 0.2 \mathrm{v} / \mathrm{v} / \mathrm{v})\end{array}$ & $280 \mathrm{~nm}$ & 0.46 & {$[68]$} \\
\hline Woodfordia fruticosa & reflux & HPLC water & $\begin{array}{l}\text { toluene: chloroform: } \\
\text { ethyl acetate: formic acid } \\
(2: 6: 6: 2)\end{array}$ & $\begin{array}{l}254 \mathrm{~nm}, \\
366 \mathrm{~nm}\end{array}$ & - & {$[69]$} \\
\hline Potentilla species & extraction & Methanol & $\begin{array}{l}\text { Toluene: ethyl formate: } \\
\text { formic acid }(6: 4: 1 \mathrm{v} / \mathrm{v} / \mathrm{v})\end{array}$ & $254 \mathrm{~nm}$ & - & {$[70]$} \\
\hline Rosa hybrida & Extraction & - & $\mathrm{CAN}: \mathrm{H}_{2} \mathrm{O}: \mathrm{HCOOH}(50: 50: 5)$ & $270 \mathrm{~nm}$ & - & {$[71]$} \\
\hline \multicolumn{7}{|c|}{ HPTLC Analysis of Ayurvedic / Traditional formulation: } \\
\hline Ashwagandharishta & decoction & Methanol & $\begin{array}{l}\text { Toluene: ethyl acetate: } \\
\text { formic acid: methanol } \\
(9: 9: 3: 0.6 \mathrm{v} / \mathrm{v} / \mathrm{v} / \mathrm{v})\end{array}$ & $285 \mathrm{~nm}$ & $\begin{array}{l}0.46 \pm \\
0.02\end{array}$ & {$[72]$} \\
\hline Triphala churnam & Extraction & Methanol & $\begin{array}{l}\text { Toluene: Ethyl Acetate: } \\
\text { Formic Acid: Methanol } \\
(3: 3: 0.8: 0.2 \mathrm{v} / \mathrm{v})\end{array}$ & $280 \mathrm{~nm}$ & 0.47 & {$[73]$} \\
\hline Dhatrinisha churna & Extraction & methanol & $\begin{array}{l}\text { toluene : ethyl acetate: } \\
\text { methanol : formic acid } \\
(16: 14: 1: 4 \mathrm{v} / \mathrm{v})\end{array}$ & $330 \mathrm{~nm}$ & - & {$[74]$} \\
\hline Arjunarishta & Decoction & methanol & $\begin{array}{l}\text { Toluene: ethyl acetate: } \\
\text { formic acid: methanol } \\
9: 9: 3: 0.6(\mathrm{v} / \mathrm{v})\end{array}$ & $285 \mathrm{~nm}$ & 0.46 & {$[75]$} \\
\hline Manjisthadi churna & Extraction & Methanol & $\begin{array}{l}\text { toluene: ethyl acetate: } \\
\text { methanol: formic acid } \\
(10: 9: 6: 5 \mathrm{v} / \mathrm{v})\end{array}$ & $280 \mathrm{~nm}$ & 0.72 & {$[76]$} \\
\hline
\end{tabular}


Ellagic acid content was determined by HPTLC in flowers of Nymphaea alba Linn, whole plant of Phyllanthus maderaspatensis Linn, and seeds of Abrus precatorius Linn. Extracts were prepared by Soxhlet extraction and dilutions were made in prepared methanol. Researchers have reported simultaneous instrumental precision for gallic acid and ellagic acid was 0.083 and 0.78 , repeatability 1.07 and $1.50(\% \mathrm{CV})$. They have also reported accuracy of the simultaneous method by a recovery study at two different levels and the average percentage recovery was found to be $101.02 \%$ for gallic acid and $102.42 \%$ for ellagic acid [68] in whole plant.

The content of ellagic acid was determined in Woodfordia fruticosa plant which was procured from three different states of India namely Himachal Pradesh, Telangana and Karnataka. The extract was prepared by refluxing sample with $50 \mathrm{ml}$ of $70 \%$ ethanol for half hour. The report showed that the presence of ellagic acid in the extracts gave bands at $R_{\mathrm{f}}$ value of 0.30 at $\mathrm{UV} 254$ and $366 \mathrm{~nm}$, which was in concordance with standard ellagic acid [69].

Bazylko and coresearcher performed fingerprinting analysis of eleven Species of Potentilla L. (Rosaceae), which were collected during different time and extracted with methanol. Their study aimed for HPTLC fingerprinting methods for different polyphenolic compounds including ellagic acid in selected Potentilla species. A mobile phase of toluene: ethyl formate: formic acid $(6: 4: 1 \mathrm{v} / \mathrm{v} / \mathrm{v})$ was used on HPTLC silica gel $60 \mathrm{~F}_{254}$ as stationary phase and developed the method. They have reported the presence of ellagic acid at $R_{\mathrm{f}} 0.13$ for all selected eleven species [70].

Polyphenol content of the various parts of plant Rosa hybrid was determined by HPTLC. Sixty compounds were reported in different parts of plant Rosa hybrid like wood, shoots, early buds, buds before flowering, flowers and leaves, including hydrolysable tannins mainly ellagic acid [71].

\subsubsection{HPTLC Analysis of Ayurvedic / Traditional Formulations}

Tiwari and co-researchers performed HPTLC on the Ashwagandharishta which is a Traditional Ayurvedic formulation containing roots of Ashwagandha, which contains ellagic acid. Studies were performed on three samples, viz, samples prepared by a traditional method, samples prepared by a modern method and samples procured from a local market. A method was developed for the said preparation, and the percentage of ellagic acid was found to be $0.0191,0.0189$ and $0.0188 \% \mathrm{w} / \mathrm{w}$ respectively [72].

Triphala churna consist of one part each of Terminalia chebula, Embellica officinalis and Terminalia bellirica. N.S. Jeganathan and K. Kannan developed HPTLC method for quantitative estimation of ellagic acid in the laboratory prepared formulation and the marketed formulation of Triphala churna. Extraction was done using the Soxhlet extraction technique with methanol and ethyl acetate. In the laboratory prepared formulation at $280 \mathrm{~nm}, 0.2 \%$ and $0.5 \%$ of ellagic acid was found in methanolic and ethyl acetate extract respectively. While in the commercial formulation, ellagic acid was obtained in methanolic and ethyl acetate extract $(0.05 \% \mathrm{w} / \mathrm{w}$ and $0.4 \% \mathrm{w} / \mathrm{w}$ respectively) [73].

Dhatrinisha churna is an Ayurvedic formulation used for the treatment of hyperlipidaemia. Patel and co-researchers had estimated the ellagic acid content by HPTLC method and also validated the method as per International Conference on Harmonization (ICH). Results showed $r^{2}>0.997$ for linear correlation coefficient, the percent RSD was less than $1.92 \%$ and recoveries were between $96.60-101.4 \%$ [74] (Table 2).

An Ayurvedic formulation called Arjunarishta, also known as Parthadhyarishta, is being used for treatment in cardiovascular disorders. A HPTLC method was developed for ellagic acid and amount of ellagic acid in Arjunarishta-T (prepared by traditional method) and Arjunarishta-M (prepared by modern method) and also in its marketed formulation was found to be $0.0361,0.0360$ and $0.0359 \% \mathrm{w} / \mathrm{w}$ respectively. Recovery was found between 99.82-99.93\% in Arjunarishta-T, 99.89-100.23\% in Arjunarishta-M and $100.04-100.13 \%$ in the marketed formulation [75] (Table 2).

In the traditional Ayurvedic system of medicine, hyperlipidaemia is treated by Manjisthadi churna. The HPTLC method of methanol extraction of churna was developed using toluene: ethyl acetate: methanol: formic acid (10:9:6:5 v/v) as a mobile phase. The extract was used for HPTLC on silica gel plates. The $\mathrm{R}_{\mathrm{f}}$ of standard ellagic acid was found to be 0.72 with densitometric scanning at $280 \mathrm{~nm}$ of the marker. The ellagic acid content was $0.534 \%$ w/w in Manjisthadi churna. Recovery values from 100.75$102.33 \%$ showed the reliability and reproducibility of the method [76] (Table 2).

\subsubsection{High Pressure Liquid Chromatography (HPLC)}

High-performance liquid chromatography (HPLC) is a technique used to separate analytes from different samples. It depends upon the chemical structure, molecular weight and nature of the analytes [77].

HPLC can be used for analysis of phytoconstituents, their degradation products and possible derivatives. It can analyze very low concentration of analytes in the presence of co-eluting components. Currently, HPLC offers the added 
advantage in the analysis of poly phenolic plant derived and biological matrices like a wide range of commercially available columns with fit-for-purpose properties having new generation sorbents and attachment of two or more columns in a switching mode. Considering all the above unique properties, HPLC is considered as one of the standard methods for analysis of ellagic acid [78].

\subsubsection{HPLC Analysis of Extracts:}

A validated rapid HPLC-PDA method was developed for quantification and identification of ellagic acid in the extracts prepared from the bark and fruits of Terminalia chebula, Terminalia bellirica, Terminalia arjuna and Terminalia catappa. Authors have reported a limit of detection and a limit of quantification for ellagic acid as $0.5 \mathrm{mg} / \mathrm{mL}$ and $1.0 \mathrm{mg} / \mathrm{mL}$ respectively. This method is suitable for quantitative analysis as well as quality control of extracts and herbal formulations from all four Terminalia species [79]. The details related to the parameters of the method are mentioned in the table 3.

A HPLC method has been developed for estimation of ellagic acid from Epilobium angustifolium (Canadian willow herb) extract. Authors have reported correlation

Table 3 Quantitative analysis of ellagic acid by HPLC methods

\begin{tabular}{|c|c|c|c|c|c|c|c|}
\hline Sample & Matrix & $\begin{array}{l}\text { Sample } \\
\text { preparation }\end{array}$ & Column & $\begin{array}{l}\text { Chromatographic } \\
\text { conditions }\end{array}$ & Detection & $\begin{array}{l}\text { RT } \\
\text { ( in Min) }\end{array}$ & Reference \\
\hline \multicolumn{8}{|l|}{ HPLC Analysis of Extracts } \\
\hline $\begin{array}{l}\text { Terminalia chebula, } \\
\text { Terminalia bellirica, } \\
\text { Terminalia arjuna and } \\
\text { Terminalia catappa }\end{array}$ & $\begin{array}{l}\text { Extracted with } \\
\text { hydro alcoholic } \\
\text { solvent } \\
\text { ( } 3: 7, \text { water : } \\
\text { methanol) }\end{array}$ & $\begin{array}{l}500 \mathrm{mg} / \\
\mathrm{mL}, \\
\text { HPLC grade } \\
\text { methanol }\end{array}$ & $\begin{array}{l}\text { RP- } 18 \text { column } \\
\text { (SunFire, Waters, } \\
\text { USA) with } 5 \mu \mathrm{m} \text {, } \\
4.6 \mathrm{~mm} \text { id, } 150 \\
\mathrm{~mm} \text { length }\end{array}$ & $\begin{array}{l}\text { acetonitrile }(A) \\
\text { And }(0.05 \%) \text { TFA in } \\
\text { water }(B, p H 2.25)\end{array}$ & PDA & - & [79] \\
\hline $\begin{array}{l}\text { Epilobium } \\
\text { angustifolium }\end{array}$ & -- & $\begin{array}{l}\text { Methanol } \\
\text { (HPLC } \\
\text { grade) }\end{array}$ & $\begin{array}{l}\text { Sunfire C18 } \\
\text { column, } 5 \mu \mathrm{m} \\
(4.6 \times 250 \mathrm{~mm})\end{array}$ & $\begin{array}{l}\text { A- } 0.1 \% \\
\text { Orthophosphoric } \\
\text { acid solution and } \\
\text { B- Acetonitrile }\end{array}$ & UV & 16 & [80] \\
\hline Eugenia uniflora & Extraction & Ethanol & $\begin{array}{l}\text { Supelco } \\
\text { Analytical C18 } \\
\text { column }(250 \times \\
4.6 \mathrm{~mm}, 5 \mu \mathrm{m})\end{array}$ & $\begin{array}{l}\text { Water: acetonitrile } \\
(85: 15)\end{array}$ & UV & 12.22 & [81] \\
\hline Woodfordia fruticosa & Reflux & $\begin{array}{l}\text { HPLC grade } \\
\text { water }\end{array}$ & $\begin{array}{l}\text { C18 } \\
(250 \mathrm{~mm} \times \\
4.6 \mathrm{~mm}), 5 \mu \mathrm{m}\end{array}$ & $\begin{array}{l}\text { acetonitrile: } 5 \\
\text { mM potassium } \\
\text { dihydrogen } \\
\text { orthophosphate } \\
\left(\mathrm{KH}_{2} \mathrm{PO}_{4}\right)(95: 5 \\
\mathrm{v} / \mathrm{v}) \text { buffer } \mathrm{pH} \\
2.5 \text { with dilute } \\
\text { orthophosphoric } \\
\text { acid }\end{array}$ & UV & 12.3 & [69] \\
\hline $\begin{array}{l}\text { Punica granatum } \\
\text { (Pomegranate Rinds) }\end{array}$ & Extraction & $\begin{array}{l}50 \% \\
\text { methanol }\end{array}$ & $\begin{array}{l}\text { Zobax SBC18 } \\
\text { column }(250 \times \\
4.6 \mathrm{~mm} \text { id; } 5 \mu \mathrm{m})\end{array}$ & $\begin{array}{l}\text { Methanol: ethyl } \\
\text { acetate: potassium } \\
\text { dihydrogen } \\
\text { phosphate: } \\
\text { phosphoric } \\
\text { acid(both at } 0.05 \\
\text { M) in the ratio } \\
34: 2: 64(\mathrm{v} / \mathrm{v} / \mathrm{v})\end{array}$ & $\begin{array}{l}\text { DAD } \\
\text { (G1365B- } \\
\text { MWD) }\end{array}$ & 10.32 & [38] \\
\hline Geum rivale & Extraction & $\begin{array}{l}\text { diethyl } \\
\text { ether }\end{array}$ & $\begin{array}{l}\text { Lichro CART }(250 \\
\times 4 \mathrm{~mm})\end{array}$ & $\begin{array}{l}\text { A: }(0.5 \% \text { water } \\
\left.\text { solution of } \mathrm{H}_{3} \mathrm{PO}_{4}\right) \\
\text { and } \mathrm{B}: \mathrm{ACN}\end{array}$ & UV/VIS & - & {$[82]$} \\
\hline Pomegranate husk & Extraction & $\begin{array}{l}60 \% \\
\text { ethanol in } \\
\text { water }\end{array}$ & $\begin{array}{l}\text { RP BDS Hypersil } \\
\text { C18 }(250 \times \\
4.6 \mathrm{~mm} \text { id, } 5 \mu \mathrm{m})\end{array}$ & $\begin{array}{l}90 \% \text { methanol and } \\
10 \% \mathrm{H}_{2} \mathrm{O}\end{array}$ & - & 13.19 & {$[62]$} \\
\hline
\end{tabular}




\begin{tabular}{|c|c|c|c|c|c|c|c|}
\hline $\begin{array}{l}\text { Jatropha dioica, } \\
\text { Euphorbia } \\
\text { antisyphyllitica, Turnera } \\
\text { diffusa, Flourensia } \\
\text { cernua, Punica } \\
\text { granatum }\end{array}$ & Extraction & $\begin{array}{l}\text { EA in } \\
\text { methanol }\end{array}$ & $\begin{array}{l}\text { Optisil ODS } \\
\text { column }(5 \mu \mathrm{m}, \\
250 \times 4.6 \mathrm{~mm})\end{array}$ & $\begin{array}{l}\text { Acetonitrile }(\mathrm{A}) \text { and } \\
\text { water : phosphoric } \\
\text { acid }(\mathrm{pH} 2.5, \mathrm{~B}) \text {, } \\
30: 70 \mathrm{v} / \mathrm{v}\end{array}$ & PAD & 5.1 & [83] \\
\hline Strawberry & $\begin{array}{l}\text { Extraction, } 80 \% \\
\text { methanol in } \\
\text { water } v / v \text { and } \\
70 \% \text { acetone in } \\
\text { water v/v }\end{array}$ & - & $\begin{array}{l}\text { Betasil C18 } \\
\text { column ( } 250 \mathrm{~mm} \\
\times 2.1 \mathrm{~mm} \text { id, } 5 \\
\mu \mathrm{m}) 5 \mu \mathrm{m} \mathrm{C} 18 \\
\text { guard column } \\
(4.0 \mathrm{~mm} \times \\
2.1 \mathrm{~mm} \mathrm{id})\end{array}$ & $\begin{array}{l}\text { (A) Acetic acid: } \\
\text { water }(2: 98, v / v) \\
\text { and (B) acetic acid: } \\
\text { acetonitrile: water } \\
(2: 50: 48, v / v / v) \text {. }\end{array}$ & DAD & - & [58] \\
\hline $\begin{array}{l}\text { Myrtle berries (Myrtus } \\
\text { communis) }\end{array}$ & Extraction & $\begin{array}{l}\text { Alcoholwa- } \\
\text { ter mixture }\end{array}$ & $\begin{array}{l}\text { C18 }(250 \mathrm{~mm} \times \\
4.6 \mathrm{~mm}, 5 \mu \mathrm{m}, \\
\text { Waters }) \text { column }\end{array}$ & $\begin{array}{l}\mathrm{A}, 0.2 \mathrm{M} \text { phosphoric } \\
\text { acid, and } \\
\text { mobile phase } \mathrm{B}, \\
\text { acetonitrile } 0.2 \mathrm{M} \\
\text { phosphoric acid } \\
(80: 20, \mathrm{v} / \mathrm{v})\end{array}$ & HPLC-UV & - & [101] \\
\hline Rosa hybrida & $\begin{array}{l}\text { Microwave } \\
\text { Assisted } \\
\text { Extraction }\end{array}$ & - & $\begin{array}{l}\text { C18 Nucleodur } \\
\text { sphinx ,150 } \times \\
4.6 \mathrm{~mm}, 5 \mu \mathrm{m}\end{array}$ & $\begin{array}{l}\text { A: } 0.1 \% \text { formic } \\
\text { acid in water, } B \text { : } \\
0.1 \% \text { formic acid in } \\
\text { methanol }\end{array}$ & DAD & - & [71] \\
\hline $\begin{array}{l}\text { Myricaria bracteata } \\
\text { leaves }\end{array}$ & Extraction & $\begin{array}{l}\text { ethanol: } \\
\text { water } \\
\text { mixture } \\
(70: 30, v / v)\end{array}$ & $\begin{array}{l}\text { Zorbax SB-C18 } \\
\text { Column }(4.6 \\
\mathrm{mm} \times 150 \mathrm{~mm} \text {, } \\
5 \mu \mathrm{m} \mathrm{id})\end{array}$ & $\begin{array}{l}\mathrm{MeOH}(\mathrm{A}) \text { and } 0.1 \% \\
\text { orthophosphoric } \\
\text { acid in water (B) }\end{array}$ & DAD & - & [84] \\
\hline $\begin{array}{l}\text { Phyllanthus emblica, } \\
\text { P. fraternus, } \\
\text { P. amarus and P. niruri }\end{array}$ & Extraction & ethanol & $\begin{array}{l}\text { ThermoBetasil } \\
\text { C } 8 \text { column }(250 \\
\mathrm{mm} \times 4.5 \mathrm{~mm} \text {, } \\
5 \mu \mathrm{m})\end{array}$ & $\begin{array}{l}0.1 \% \text { formic acid } \\
\text { in water }(A) \text { and } \\
0.1 \% \text { formic acid in } \\
\text { methanol (B) }\end{array}$ & DAD & - & [99] \\
\hline Muscadine grapes & Extraction & $\begin{array}{l}\text { acidified } \\
\text { methanol }\end{array}$ & $\begin{array}{l}250 \mathrm{~mm} \times 4.6 \\
\mathrm{~mm} \text { Acclaim } \\
120 \text { C18 } \\
\text { column (Dionex, } \\
\text { Sunnyvale, } \\
\text { CA) C18 guard } \\
\text { column }\end{array}$ & $\begin{array}{l}\text { water (phase } \mathrm{A}) \\
\text { and } 60 \%(\mathrm{v} / \mathrm{v}) \\
\text { methanol (phase } \\
\text { B) both adjusted } \\
\text { to } \mathrm{pH} 2.4 \text { with } \\
\text { orthophosphoric } \\
\text { acid }\end{array}$ & $\begin{array}{l}\text { PDA-100 } \\
\text { detector }\end{array}$ & - & [98] \\
\hline \multicolumn{8}{|c|}{ HPLC Analysis of Herbal Product: } \\
\hline $\begin{array}{l}\text { Roots of Salacia } \\
\text { species, leaves of } \\
\text { Lagestroemia parviflora } \\
\text { and fruit rind of } \\
\text { Garcinia indica }\end{array}$ & Extraction & methanol & $\begin{array}{l}\text { Phenomenex } \\
\text { C18 column } \\
(250 \mathrm{~mm} \times \\
4.6 \mathrm{~mm} \text { id, } 5 \mu \mathrm{m} \\
\text { pore size })\end{array}$ & $\begin{array}{l}\text { A: acetonitrile B: } \\
\text { buffer solution } \\
(0.03 \% \mathrm{v} / \mathrm{v} \\
\text { Phosphoric acid) } \\
45: 55 \mathrm{v} / \mathrm{v}\end{array}$ & $\begin{array}{l}\text { SPD-M20A } \\
\text { - PDA }\end{array}$ & 6.09 & [90] \\
\hline $\begin{array}{l}\text { Strawberry jam, } \\
\text { Blueberry jam and } \\
\text { Raspberry jam }\end{array}$ & Decoction & $\begin{array}{l}\text { homoge- } \\
\text { nized in } \\
\text { methanol }\end{array}$ & $\begin{array}{l}\text { L-column ODS } \\
(5 \mu \mathrm{m}, 250 \times 4.6 \\
\mathrm{mm} \text { id })\end{array}$ & $\begin{array}{l}5 \mathrm{mM} \text { potassium } \\
\text { dihydrogen } \\
\text { phosphate solution } \\
(\mathrm{pH} 2.5) \text {-acetonitrile } \\
(41: 9 \mathrm{v} / \mathrm{v})\end{array}$ & DAD & - & [2] \\
\hline Muscadine grapes & $\begin{array}{l}\text { (acetone: } \mathrm{H}_{2} \mathrm{O} \text { : } \\
\text { acetic acid, } \\
70: 29.7: 0.3, \mathrm{v} / \mathrm{v} \text { ) }\end{array}$ & - & $\begin{array}{l}\text { Zorbax } \\
\text { Stablebond } \\
\text { Analytical } \\
\text { SB-C18 column } \\
(4.6 \mathrm{~mm} \times 250 \\
\mathrm{mm}, 5 \mu \mathrm{m}\end{array}$ & $\begin{array}{l}\text { A ( } 0.5 \% \text { formic acid } \\
\text { aqueous solution) } \\
\text { and mobile phase B } \\
\text { (methanol) }\end{array}$ & DAD & - & [36] \\
\hline
\end{tabular}




\begin{tabular}{|c|c|c|c|c|c|c|c|}
\hline \multicolumn{8}{|c|}{ HPLC analysis of Standard Ellagic acid } \\
\hline Ellagic acid & Dilution & $\begin{array}{l}\text { Stock } \\
\text { solution in } \\
\text { methanol } \\
\text { and } \\
\text { working } \\
\text { standards } \\
\text { with pH } 7.4 \\
\text { phosphate } \\
\text { buffer }\end{array}$ & $\begin{array}{l}\text { polar reverse } \\
\text { phase PEG } \\
\text { bonded column }\end{array}$ & $\begin{array}{l}5 \mathrm{mM} \text { potassium } \\
\text { dihydrogen } \\
\text { orthophosphate } \mathrm{pH} \\
2.5 \text { and acetonitrile } \\
(20: 80, \mathrm{v} / \mathrm{v})\end{array}$ & $\begin{array}{l}\text { UV (SPD- } \\
10 A v p)\end{array}$ & 4.0 & [49] \\
\hline Ellagic acid & Dissolution & $\begin{array}{l}\text { Dissolved } \\
\text { in } 100 \% \\
\text { methanol }\end{array}$ & $\begin{array}{l}\text { RP C18 Acclaim, } \\
3 \mu \mathrm{m}, 4.6 \times 150 \\
\text { mm column }\end{array}$ & $\begin{array}{l}\text { (A) } 0.1 \text { vol. } \% \text { formic } \\
\text { acid in water and } \\
\text { (B) } 0.1 \text { vol. \% formic } \\
\text { acid in acetonitrile }\end{array}$ & $\begin{array}{l}\text { PDA (SPD- } \\
\text { M10Avp) }\end{array}$ & - & [57] \\
\hline
\end{tabular}

coefficient $\left(\mathrm{r}^{2}\right)>0.999$, the \% RSD of peak area of standard solution less than $2.0 \%$. The accuracy of the method was checked by the average \% recovery and was found within the acceptable range of $98-102 \%$ [80].

The quantification of ellagic acid in ethanolic extracts of Eugenia uniflora L. (Myrtaceae) leaves was done by the HPLC-UV method and the same was later developed and validated. To study the effects of the ethanol concentration, extraction time and temperature on the ellagic acid, the ultrasound-assisted extraction (UAE) was performed by a Box Behnken design $\left(3^{3}\right)$ combined with response surface methodology. Assuncao and co-researchers have reported that, by the use of UAE, extraction yield of the ellagic acid was highest using ethanol as a solvent [81].

Indian origin plant Woodfordia fruticosa, is widely used as folk medicine for the treatment of various diseases. Researchers have collected samples of Woodfordia fruticosa from three different states of India viz, Telangana, Karnataka, Himachal Pradesh and performed the HPLC analyses of the extract of flowers of Woodfordia fruticosa to determine the presence of ellagic acid. The report showed that, the peak at a retention time of 12.3 min was common in all the three samples and matches with the ellagic acid standard sample [69].

Ellagic acid was analyzed in hydrolyzed extracts of Punica granatum (pomegranate rinds) by the HPLC method and the report showed that retention time for ellagic acid was $10.32 \mathrm{~min}$, detection limit $2.8 \mu \mathrm{g} / \mathrm{mL}$, relative standard deviation for the within-day precision was $1.23 \%$, and average recovery was $98.32 \%$. The report showed that this method can be applied to the quality control of pomegranate rinds [38].

Investigation of biologically active constituent of Geum rivale was done by RP-HPLC. Owczarek and co-researchers have analyzed a total of eleven phenolic acids from aerial parts and eight in underground parts of the plant. The extract was prepared with petroleum ether and chloroform using a Soxhlet apparatus. They also reported a retention time of ellagic acid around $40 \mathrm{~min}$ [82].

Finely ground pomegranate husk was extracted three times with $60 \%$ ethanol water solution, and then kept for five hours in $5.0 \% \mathrm{H}_{2} \mathrm{SO}_{4}$ for acid hydrolysis. After that, recrystalization was done with methanol to obtain over $90 \%$ pure ellagic acid. Later on it was recrystallized from hot pyridine and resulted in $>99 \%$ pure crystalline ellagic acid. This ellagic acid was then used for HPLC analysis, which resulted in a RT of $13.79 \mathrm{~min}$ [62].

Five different plants, Jatropha dioica branches, Euphorbia antisyphyllitica branches, Turnera diffusa leaves, Flourensia cernua leaves and Punica granatum husk were collected, finely powdered and subjected to ellagic acid extraction along with HPLC analysis. The report showed that, different quantities of ellagic acid in these plants like, Punica granatum turning $33.79 \pm 7.43$, Punica granatum red 12.80 \pm 5.83 , Euphorbia antisyphyllitica $2.18 \pm 0.39$, Flourensia cernua $1.59 \pm 0.96$, Tumera diffusa $0.87 \pm 0.59$, Jatropha dioica $0.81 \pm 0.43 \mathrm{mg} / \mathrm{g}$ [83].

HPLC analysis of Fragaria $\times$ ananassa was done by Aaby and co-researchers using two mobile phases acetic acid: water $(2: 98 \mathrm{v} / \mathrm{v})$ and acetic acid: acetonitrile: water (2:50:48 v/v/v) with a Betasil C18 column. Aaby and co-researchers have reported a retention time of $55.1 \mathrm{~min}$ for ellagic acid at $368 \mathrm{~nm}$ [58].

HPLC-DAD analysis of six different parts of the plant Rosa hybrid was carried out for the initial identification of the polar compounds present in each six different organs (like wood, shoots, early buds, buds before flowering, flowers, leaves). Using a detection wavelength of 270 $\mathrm{nm}$, Riffault and co-researchers have reported $29.2 \mathrm{~min}$ retention time for ellagic acid [71].

Myricaria bracteata leaves showed a retention time of ellagic acid at $10.6 \mathrm{~min}$. The mobile phase consisted of methanol and 0.1\% orthophosphoric acid in water 50:50 (v/v) [84]. 
The grape seed extracts were analyzed by HPLC-DAD system and the results showed the presence of ellagic acid in the processed methanolic and acidified methanolic extract. The reported concentration of ellagic acid in the grape seed extract was $0.08 \mathrm{mg} / \mathrm{g}$ with retention time of $22.7 \mathrm{~min}$ and regression $\left(\mathrm{R}^{2}\right)$ was 0.9975 [85].

The juice of Syzygium cumini fruits and dehydrated powders obtained by foam mat drying and lyophilization of juice were analyzed for presence of phenolic compounds. HPLC with a diode array detection coupled with an electrospray ionization mass spectrometry was used for the analysis. Juice production resulted in the extraction of hydrolysable tannins [86,87,88]. Chromatographic conditions were as follows- Merck LiChrospher RP18e (5 $\mu \mathrm{m})$ column ( $25 \mathrm{~cm} \times 4 \mathrm{~mm}$ id) with the following elution conditions: linear gradient from 0 to $90 \%$ solvent $\mathrm{B}$; solvent A: $\mathrm{H}_{2} \mathrm{O}: \mathrm{H}_{3} \mathrm{PO}_{4}$ (990:1); solvent $\mathrm{B}: \mathrm{MeOH}-\mathrm{H}_{3} \mathrm{PO}_{4}$ (990:1); gradient duration: 30 rain; flow speed: $1 \mathrm{ml} / \mathrm{min}$. Detection: UV $280 \mathrm{~nm}$. The reported retention time was $25.0 \mathrm{~min}$ for ellagic acid [89].

\subsubsection{HPLC Analysis of Herbal Formulations}

A herbal formulation containing of leaves of Lagestroemia parviflora, roots of Salacia oblonga and Salacia roxbhurghii and fruit rind of Garcinia indica was studied for ellagic acid content. The HPLC report for ellagic acid showed LOD and LOQ values as $4.62 \mu \mathrm{g} / \mathrm{mL}$ and $14.01 \mu \mathrm{g} /$ $\mathrm{mL}$, respectively. Repeatability and recovery studies were in between 95-103\%, precision of the intra-day and inter day percent Relative Standard Deviation by HPLC measurementswere1.05\% and $2.22 \%$, respectively. The reported retention time was $6.09 \mathrm{~min}$. The developed and validated method was suitable for routine analysis of herbal formulation [90].

Recoveries of ellagic acid from fresh fruits viz. Strawberry, Pineapple and Raspberry and products viz. Strawberry jam, Blueberry jam and Raspberry jam. The analyses showed recoveries of EA from the samples were found to be 90.1 to $98.3 \%$ (SD 0.9 to $5.0 \%$ ). The reported LOD and LOQ were $0.015 \mathrm{mg} / \mathrm{g}$ and $0.05 \mathrm{mg} / \mathrm{g}$ for ellagic acid respectively [2].

Sandhu and co-researchers have used HPLC-DAD to identify the phenolic compounds of Muscadine grapes in the seeds, skin and pulp. In the seeds, skin and pulp the average reported percentage of phenolic compounds were 87.1, 11.3 and $1.6 \%$ respectively. The presence of ellagic acid is exclusive and unique in Muscadine grapes, and it is available in different forms like ellagitannins, ellagic acid glycosides and free ellagic acid [36].

\subsubsection{HPLC Analysis of Standard Ellagic Acid:}

Studies on ellagic acid by Bala and co-researchers have reported a correlation coefficient of 0.9982 . The reported LOD was $0.1 \mathrm{~g} / \mathrm{ml}$ and range of accuracy was $98-103 \%$ indicating a good agreement between the actual and practical values. Bala and co-researchers have also reported elution of ellagic acid on the stationary phase which is bonded with polyethylene glycol resulted in a narrower peak and reduced tailing in comparison to a regular reverse phase C18 column [49].

The ellagic acid standard was dissolved in methanol and then subjected to more detailed validation by Williams and co-researchers. They selected 0.1 vol. $\%$ formic acid in water and $0.1 \mathrm{vol} . \%$ formic acid in acetonitrile as a mobile phase. The reported results for the validation showed the recovery values of $100 \%$. Reported LOD and LOQ for ellagic acid were $0.06 \mu \mathrm{g} / \mathrm{mL}$ and $0.17 \mu \mathrm{g} / \mathrm{mL}$, respectively [57].

\subsubsection{Gas Chromatography-Mass Spectrometry (GC-MS):}

Gas Chromatography is well known and sound analytical technique generally used for the quantification, characterization and identification of volatile compounds. It has powerful separation capacity and very sensitive detection which have made this chromatographic technique a useful tool for the analysis [91]. Despite its several advantages, application of this method is limited to the essentials oils because of the chances of thermal degradation of the compounds [92]. When used in combination with mass spectrometry, this method gives high selectivity and sensitivity [93].

Analysis of Geum rivale was done by GC-MS whereby aerial and underground parts were used, this belongs to a particular plant family and subfamily which contains large amounts of tannins (polyphenolic compounds) like ellagic acid. The extract of the same was prepared with petroleum ether and chloroform in the Soxhlet apparatus. An Agilent $6890 \mathrm{~N}$ gas chromatograph with an Agilent 5973 mass detector was used for the GC-MS analysis. The electron impact at $70 \mathrm{eV}$ was used as ionization potential. Owczarek and co-researchers have reported about 130 $\mathrm{mg} / \mathrm{g}$ content of tannins in underground parts of the plant [82].

Tannins in the grape, oak and wine extracts were analyzed by GC-MS. The report showed that; ellagic acid was present in oak and wine extract by GC-MS. The analysis was performed using a GC 6890N/MSD 5973B Agilent instrument. The reported retention time for ellagic acid was $33.84 \mathrm{~min}$ [94]. 
GC-MS analysis for the phytoconstituent of Salacia chinensis L. was performed. The analysis was done with 60 M RTX 5MS a nonpolar column. A split less mode technique was used to inject $2 \mu \mathrm{l}$ samples. Mass spectra was recorded over 35-650 atomic mass unit (AMU) range with electron impact ionization energy $70 \mathrm{eV}$. GraphPad Prism was used to perform statistical analysis. The author has reported the presence of ellagic acid equivalent per gram dry weight into root, stem, leaf, fruit pulp and seeds by different extraction method [95].

\subsubsection{Liquid Chromatography - Mass Chromatography (LC-MS):}

Liquid chromatography (LC) separates the components of a sample based on differences in their retention strength or affinity for the stationary phase or mobile phase, and then detects the separated components using various analytical techniques such as UV, fluorescence or electrical conductivity based on their properties.

Mass spectrometry (MS) is known for its highly sensitive detection process that ionizes the sample components using various methods, such as electrospray ionization, chemical ionization, fast atom bombardment, laser desorption etc. and then separates the resulting ions in vacuum based on their mass-to-charge ratios and measures the intensity of each ion.

Therefore, LC-MS systems combine the outstanding separation resolution of liquid chromatography with the outstanding qualitative capabilities of mass spectrometry. The MS creates and detects charged ions. The LC-MS data may be used to provide information about the molecular weight, structure, identity and quantity of specific sample components.

Ethanolic extract of Pomegranate peel was analyzed by LC-MS and the identification of ellagic acid was done by comparison with a reference standard. The report showed that the $[\mathrm{M}-\mathrm{H}]$ at $\mathrm{m} / \mathrm{z} 301$ confirms the presence of ellagic acid. The same component in MS-MS produces fragments at $\mathrm{m} / \mathrm{z} 258,229$ and 185 using the electrospray ionization technique [96].

Method development and quantification of ellagic acid derivatives was done in four Drosera species viz., Drosera anglica, $D$. intermedia, D. madagascariensis and D. rotundifolia. Along with ellagic acid, several other compounds were detected and identified by LC-MS. Droserae herba LC-MS analysis was performed with an UltiMate 3000 RSLC-series system (Dionex, Germering, Germany) coupled to a 3D quadrupole ion-trap mass spectrometer equipped with an orthogonal ESI source. For ellagic acid $[\mathrm{M}-\mathrm{H}]^{-}$showed at 300.9 and main fragments include 283.8, 270.8, 256.8, 228.9, 212.8, 200.8, 184.9 [97]. Lee and other co-researchers have reported ellagic acid in Muscadine Grapes by HPLC-ESI-MS. They have reported base peak (m/z) at 301; [M-H]; MS $^{2}(\mathrm{~m} / \mathrm{z})$ at 301, 284, 257, 229, 185 for ellagic acid [98].

LC-MS analysis of Fragaria $\times$ ananassa was done by Aaby and co-researchers. They have allowed LC elute directly into ESI interface without splitting. The nebulizer pressure was at $40 \mathrm{psi}$, dry gas flow at $10 \mathrm{~L} / \mathrm{min}$; dry temperature was at $350^{\circ} \mathrm{C}$ and capillary voltage at $3.5 \mathrm{kV}$ maintained. They have reported a peak at $[\mathrm{M}-\mathrm{H}]^{-}$at $\mathrm{m} / \mathrm{z}$ 301 and $\mathrm{MS}^{2}$ fragmentation ions in negative mode at $\mathrm{m} / \mathrm{z}$ 257,229 , and 185, typical fragments of ellagic acid [58].

Identification of ellagic acid in Myricaria bracteata leaves was done by Chernonosov and co-researchers. They have reported that molecular ion $[\mathrm{M}-\mathrm{H}]^{-}$at $\mathrm{m} / \mathrm{z} 301$ and a fragment ion at $\mathrm{m} / \mathrm{z} 284,257,229,185$ is of ellagic acid [84].

Ellagic acid and their derivatives in ethanolic extracts of Phyllanthus emblica, P. fraternus, P. amarus and P. niruri were detected using HPLC coupled with quadrupole timeof-flight tandem mass spectrometry (HPLC-ESI-QTOF-MS/ MS). The authors had reported retention time of $14.07 \mathrm{~min}$ for ellagic acid and $[\mathrm{M}-\mathrm{H}]^{-}=300.999$, whereas fragment ions (Relative intensity \%) were 283.9975 (66), 245.0085 (36), 229.0135 (45), 200.0103 (58), 185.0242 (39), 173.0232 for ellagic acid [99].

Muscadine grapes HPLC-ESI-MS analysis was done by Lee and co-researchers for the determination of ellagic acid in the isolate. Presence of ellagic acid was confirmed by its $m / z 301[\mathrm{M}-\mathrm{H}]$ ion, yielding characteristic ions at $\mathrm{m} / z 257$ and 229 upon dissociation [98].

\subsubsection{Other Miscellaneous Methods:}

Capillary Zone Electrophoresis (CZE) is also a widely used method to determine the concentration of active constituents from the sample of plant extracts. A diverse group of scientists are working on this technique as an alternative tool for the identification of the acid.

Costa and researchers have reported a method for the determination of ellagic acid by CZE and compared the results obtained with GC-MS in Eucalyptus globulus wood. Moreover they have reported that, this is the first application of CZE at industrial streams for the detection of ellagic acid from cellulosic pulp production. The reported results by CZE were 959 to $986 \mathrm{mg} / \mathrm{kg}$ where as by GC-MS results were 1232 to $1083 \mathrm{mg} / \mathrm{kg}$ for ellagic acid. This showed that, both methods do not give significantly different values for ellagic acid [100]. 
Zhou and co researchers have performed the Capillary Electrophoresis (CE) of the Pomegranate rinds and compared the results with HPLC. The detection limits for HPLC and CE were 2.8 and $2.2 \mu \mathrm{g} / \mathrm{mL}$, respectively. Average recoveries were $98.32 \pm 1.2 \%$ for HPLC and $96.52 \pm 2.8 \%$ for CE. The reported results state that the CE method required less solvent and gave better column efficiency, whilst the HPLC method provided superior precision [38].

\section{Conclusion}

Tannins are an important class of phytochemicals which have been reported to have various pharmacological activities. Ellagic acid is an important phytoconstituent belonging to the class of tannins. Considering the importance of the ellagic acid in various ailments, it is also necessary to study different analytical approaches to identify and quantify ellagic acid in natural sources. The reports of all the methods described in the present review area compilation of the research done by various scientists on the estimation of ellagic acid on various instruments, and studies done on different kinds of samples. The data suggest that, the methods can be used for raw materials to final products, to determine the concentration of ellagic acid, which is an important aspect for stability of product or formulation.

\section{Conflict of Interest:}

The authors declare that they have no conflict of interest.

\section{References:}

[1] Siriwoharn T, Wrolstad RE, Durst RW. Identification of Ellagic acid in Blackberry Juice Sediment. J Food Sci. 2006;70(3):C189-97.

[2] Amakura Y, Okada M, Tsuji S, Tonogai Y. High-Performance Liquid Chromatographic Determination with Photodiode Array Detection of Ellagic acid in Fresh and Processed Fruits. J Chromatogr A. 2000;896:87-93.

[3] Niemetz R, Gross GG. Enzymology of Gallotannin and Ellagitannin Biosynthesis. Phytochemistry. 2005;66:2001-11.

[4] Plaza M, Domínguez-Rodríguez G, Castro-Puyana M, Marina ML. Polyphenols Analysis and Related Challenges. Polyphenols: Properties, Recovery, and Applications. Elsevier; 2018. pp. 177-232.

[5] Sieniawska E, Baj T. Tannins. Pharmacognosy: Fundamentals, Applications and Strategy. Elsevier Inc.; 2017. pp. 199-232.

[6] Laddha AP, Kulkarni YA. Tannins and Vascular Complications of Diabetes: an Update. Phytomedicine. 2019;56:229-45.
[7] Meyer AS, Heinonen M, Frankel EN. Antioxidant Interactions of Catechin, Cyanidin, Caffeic acid, Quercetin, and Ellagic acid on Human LDL Oxidation. Food Chem. 1998;61(1-2):71-5.

[8] Priyadarsini KI, Khopde SM, Kumar SS, Mohan H. Free Radical Studies of Ellagic acid, a Natural Phenolic Antioxidant. J Agric Food Chem. 2002;50(7):2200-6.

[9] Seeram NP, Adams LS, Henning SM, Niu Y, Zhang Y, Nair MG, et al. In Vitro Antiproliferative, Apoptotic and Antioxidant Activities of Punicalagin, Ellagic acid and a Total Pomegranate Tannin Extract Are Enhanced in Combination with Other Polyphenols as Found in Pomegranate Juice. J Nutr Biochem. 2005;16(6):360-7.

[10] Soh PN, Witkowski B, Olagnier D, Nicolau ML, Garcia-Alvarez MC, Berry A, et al. In Vitro and In Vivo Properties of Ellagic acid in Malaria Treatment. Antimicrob Agents Chemother. 2009;53(3):1100-6.

[11] Corbett S, Daniel J, Drayton R, Field M, Steinhardt R, Garrett N. Evaluation of the Anti-Inflammatory Effects of Ellagic acid. J Perianesth Nurs. 2010;25(4):214-20.

[12] Derosa G, Maffioli P, Sahebkar A. Ellagic acid and its role in chronic diseases. Adv Exp Med Biol. 2016;928:473-9.

[13] Hussein MZ, Al Ali SH, Zainal Z, Hakim MN. Development of Antiproliferative Nanohybrid Compound with Controlled Release Property Using Ellagic acid as the Active Agent. Int J Nanomedicine. 2011;6(1):1373-83.

[14] Losso JN, Bansode RR, Trappey A, Bawadi HA, Truax R. In Vitro Anti-Proliferative Activities of Ellagic Acid. J Nutr Biochem. 2004;15(11):672-8.

[15] García-Niño WR, Zazueta C. Ellagic acid: Pharmacological Activities and Molecular Mechanisms Involved in Liver Protection. Pharmacol Res. 2015;97:84-103.

[16] Jin F, Cheng D, Tao JY, Zhang SL, Pang R, Guo YJ, et al. Anti-Inflammatory and Anti-Oxidative Effects of Corilagin in a Rat Model of Acute Cholestasis. BMC Gastroenterol. 2013;13(1):79-89.

[17] Ahn D, Putt D, Kresty L, Stoner GD, Fromm D, Hollenberg PF. The Effects of Dietary Ellagic acid on Rat Hepatic and Esophageal Mucosal Cytochromes P450 and Phase II Enzymes. Carcinogenesis. 1996;17(4):821-8.

[18] Umesalma S, Sudhandiran G. Differential Inhibitory Effects of the Polyphenol Ellagic acid on Inflammatory Mediators NF-KB, INOS, COX-2, TNF- $\alpha$, and IL-6 in 1,2-DimethylhydrazineInduced Rat Colon Carcinogenesis. Basic Clin Pharmacol Toxicol. 2010;107(2):650-5.

[19] Rossi M, Erlebacher J, Zacharias DE, Carrell HL, Iannucci B. The Crystal and Molecular Structure of Ellagic acid Dihydrate: A Dietary Anti-Cancer Agent. Carcinogenesis. 1991;12(12):2227-32.

[20] Ascacio A, Sepulveda L, Aguilar CN, Rodriguez-Herrera R, Aguilera-Carbo A. Ellagic acid: Biological Properties and Biotechnological Development for Production Processes. Afr J Biotechnol. 2011;10(22):4518-23.

[21] Chen GH, Lin YL, Hsu WL, Hsieh SK, Tzen JT. Significant Elevation of Antiviral Activity of Strictinin from Pu'er Tea after Thermal Degradation to Ellagic acid and Gallic acid. Yao Wu Shi Pin Fen Xi. 2015;23(1):116-23.

[22] Park SW, Kwon MJ, Yoo JY, Choi HJ, Ahn YJ. Antiviral activity and possible mode of action of ellagic acid identified in Lagerstroemia speciosa Leaves toward Human Rhinoviruses. BMC Complement Altern Med. 2014;14(1):171. 
[23] Oliveira de MR. The Effects of Ellagic acid upon Brain Cells: A Mechanistic View and Future Directions. Neurochemical Research. Springer. 2016;41(6):1219-28.

[24] Silva da Pinto M. Carvalho de JE, Lajolo FM, Genovese MI, Shetty K. Evaluation of Antiproliferative, Anti-Type 2 Diabetes, and Antihypertension Potentials of Ellagitannins from Strawberries (Fragaria $\times$ Ananassa Duch.) Using In Vitro Models. J Med Food. 2010;13(5):1027-35.

[25] Wang D, Chen Q, Liu B, Li Y, Tan Y, Yang B. Ellagic acid Inhibits Proliferation and induces apoptosis in Human Glioblastoma Cells. Acta Cir Bras. 2016;31(2):143-9.

[26] Hemmati AA, Olapour S, Varzi HN, Khodayar MJ, Dianat M, Mohammadian B, et al. Ellagic acid Protects against Arsenic Trioxide-Induced Cardiotoxicity in Rat. Hum Exp Toxicol. 2018;37(4):412-9.

[27] Lin MC, Yin MC. Preventive Effects of Ellagic acid against Doxorubicin-Induced Cardio-Toxicity in Mice. Cardiovasc Toxicol. 2013;13(3):185-93.

[28] Chinsembu KC. Tuberculosis and Nature's Pharmacy of Putative Anti-Tuberculosis agents. Acta Trop. 2016;153:46-56.

[29] Ramírez de Molina A, Vargas T, Molina S, Sánchez J, MartínezRomero J, González-Vallinas M, et al. The Ellagic acid Derivative 4,4'-Di-O-Methyl ellagic acid Efficiently Inhibits Colon Cancer Cell Growth through a Mechanism Involving WNT16. J Pharmacol Exp Ther. 2015;353(2):433-44.

[30] Masamune A, Satoh M, Kikuta K, Suzuki N, Satoh K, Shimosegawa T. Ellagic acid Blocks Activation of Pancreatic Stellate Cells. Biochem Pharmacol. 2005;70(6):869-78.

[31] Han DH, Lee MJ, Kim JH. Antioxidant and Apoptosis-inducing activities of Ellagic acid. Anticancer Res. 2006;26 5A:3601-6.

[32] Baek B, Lee SH, Kim K, Lim HW, Lim CJ. Ellagic acid plays a protective role against UV-B-Induced Oxidative Stress by up-Regulating Antioxidant Components in Human Dermal Fibroblasts. Korean J Physiol Pharmacol. 2016;20(3):269-77.

[33] Hseu YC, Chou CW, Senthil Kumar KJ, Fu KT, Wang HM, Hsu LS, et al. Ellagic acid Protects Human Keratinocyte (HaCaT) Cells against UVA-Induced Oxidative Stress and Apoptosis through the Upregulation of the HO-1 and Nrf-2 Antioxidant Genes. Food Chem Toxicol. 2012;50(5):1245-55.

[34] Aguilar-Zarate P, Wong-Paz JE, Buenrostro-Figueroa JJ, Ascacio JA, Contreras-Esquivel JC, Aguilar CN. Ellagitannins: Bioavailability, Purification and Biotechnological Degradation. Mini Rev Med Chem. 2017;18(15):1244-52.

[35] Merck. Ellagic acid https://www.sigmaaldrich.com/catalog/ product $/$ sial/14668?lang=en $\&$ region $=$ IN (accessed Nov 10, 2019).

[36] Sandhu AK, Gu L. Antioxidant Capacity, Phenolic Content, and Profiling of Phenolic Compounds in the Seeds, Skin, and Pulp of Vitis Rotundifolia (Muscadine Grapes) as Determined by HPLC-DAD-ESI-MSn. J Agric Food Chem. 2010;58(8):4681-92.

[37] Vattem DA, Ghaedian R, Shetty K. Enhancing Health Benefits of Berries through Phenolic Antioxidant Enrichment: Focus on Cranberry. Asia Pacific Journal of Clinical Nutrition. Asia Pac J Clin Nutr. 2005;14(2):120-30.

[38] Zhou B, Wu Z, Li X, Zhang J, Hu X. Analysis of Ellagic acid in Pomegranate Rinds by Capillary Electrophoresis and High-Performance Liquid Chromatography. Phytochem Anal. 2008;19(1):86-9.

[39] Kang I, Buckner T, Shay NF, Gu L, Chung S. Improvements in Metabolic Health with Consumption of Ellagic acid and
Subsequent Conversion into Urolithins: evidence and Mechanisms. Adv Nutr. 2016;7(5):961-72.

[40] Cuadrado-Silva CT, Pozo-Bayón MÁ, Osorio C. Targeted Metabolomic Analysis of Polyphenols with Antioxidant Activity in Sour Guava (Psidium friedrichsthalianum Nied.) Fruit. Molecules. 2017;22(1):11-21.

[41] Sánchez-González C, Ciudad C), Noé V, Izquierdo-Pulido M. Health Benefits of Walnut Polyphenols: An Exploration beyond Their Lipid Profile. Crit Rev Food Sci Nutr. 2017;57(16):3373-83.

[42] Marella S. Antidiabetic plant proteins/peptides as complementary and alternative medicine- Analytical Perspectives. Rev Anal Chem. 2018;37(4):1-20.

[43] Ram M, Abdin MZ, Khan MA, Jha P. HPTLC Fingerprint Analysis: A Quality Control for Authentication of Herbal Phytochemicals. In High-Performance Thin-Layer Chromatography (HPTLC); Springer -Verlag Berlin Heidelberg, 2011;105-16.

[44] Attimarad M, Mueen Ahmed KK, Aldhubaib BE, Harsha S. High-Performance Thin Layer Chromatography: A Powerful Analytical Technique in Pharmaceutical Drug Discovery. Pharm Methods. 2011;2(2):71-5.

[45] Hua-Bin Z, Ai-Qin D, Xin-Ling Z, Pei-Hai W, Wei-Jie L, Guo-Sheng Y, et al. Quality Control Methodology and Their Application in Analysis on HPLC Fingerprint Spectra of Herbal Medicines. Chromatogr Res Int. 2012;1-12.

[46] Boligon AA, Athayde ML. Importance of HPLC in Analysis of Plants Extracts. Austin Chromatogr. 2014;1(3):2-3.

[47] Kumar BR. Application of HPLC and ESI-MS Techniques in the Analysis of Phenolic Acids and Flavonoids from Green Leafy Vegetables (GLVs). J Pharm Anal. 2017;7(6):349-64.

[48] Sarker SD, Nahar L. Hyphenated Techniques and Their Applications in Natural Products Analysis. Methods Mol Biol. 2012;864:301-40.

[49] Bala I, Bhardwaj V, Hariharan S, Kumar MN. Analytical methods for assay of Ellagic acid and its Solubility Studies. J Pharm Biomed Anal. 2006;40(1):206-10.

[50] Ellagic Acid PubChem. Https://Pubchem.Ncbi.Nlm.Nih.Gov/ Compound/Ellagic-Acid (accessed Nov 10, 2019).

[51] Acid E. Ellagic Acid | The Merck Index Online https:// www.rsc.org/Merck-Index/monograph/m4872/ellagic acid?q=unauthorize (accessed Nov 10, 2019).

[52] Schulenburg K, Feller A, Hoffmann T, Schecker JH, Martens $S$, Schwab W. Formation of $\beta$-Glucogallin, the Precursor of Ellagic Acid in Strawberry and Raspberry. J Exp Bot. 2016;67(8):2299-308.

[53] Feldman KS, Sahasrabudhe K, Smith RS, Scheuchenzuber WJ. Immunostimulation by Plant Polyphenols: A Relationship between Tumor Necrosis Factor- $\alpha$ Production and Tannin Structure. Bioorg Med Chem Lett. 1999;9(7):985-90.

[54] Aguilera-Carbo A, Augur C, Prado-Barragan LA, Favela-Torres E, Aguilar CN. Microbial Production of Ellagic Acid and Biodegradation of Ellagitannins. Appl Microbiol Biotechnol. 2008 Feb;78(2):189-99.

[55] Jia-hong C, Dong-mei W, Yong-mei W, Zai-song W. Determination of Ellagic acid Content by Ultraviolet Spectrophotometry J. Biomass Chem. Eng. 2007;41(3):18-20.

[56] Budavari S. The Merck Index. 12th ed. New Jersey: Merck and Co. Inc.; 1996.

[57] Williams DJ, Edwards D, Chaliha M, Sultanbawa Y. Measuring Free Ellagic acid: Influence of Extraction Conditions on 
Recovery by Studying Solubility and UV-Visible Spectra. Chem Pap. 2016;70(8):1078-86.

[58] Aaby K, Ekeberg D, Skrede G. Characterization of Phenolic Compounds in Strawberry (Fragaria x Ananassa) Fruits by Different HPLC Detectors and Contribution of Individual Compounds to Total Antioxidant Capacity. J Agric Food Chem. 2007;55(11):4395-406.

[59] Hasegawa M, Terauchi M, Kikuchi Y, Nakao A, Okubo J, Yoshinaga T, et al. Deprotonation Processes of Ellagic acid in Solution and Solid States. Monatsh Chem. 2003;134(6):811-21.

[60] Wilson TC, Hagerman AE. Quantitative Determination of Ellagic acid. J Agric Food Chem. 1990;38(8):1678-83.

[61] Press RE, Hardcastle D. Some Physico-Chemical Properties of Ellagic acid. J. Appl. Chem. 2007;19(9):247-51.

[62] Goriparti S, Harish MN, Sampath S. Electronic Supplementary Information for Ellagic acid - A Novel Organic Electrode Material for High Capacity Lithium Ion Batteries. R. Soc. Chem. 2013;49(65):7234-6.

[63] Ramu B, Chittela KB. High Performance Thin Layer Chromatography and Its Role Pharmaceutical Industry [Review]. Open Sci. J. Biosci. Bioeng. 2018;5(3):29-34.

[64] Morschheuser L, Wessels H, Pille C, Fischer J, Hünniger T, Fischer M, et al. HPTLC-Aptastaining - Innovative Protein Detection System for High-Performance Thin-Layer Chromatography. Sci Rep. 2016;6(1):26665:1-8.

[65] Jayachandran Nair CV, Ahamad S, Khan W, Anjum V, Mathur R. Development and Validation of High-Performance Thin-Layer Chromatography Method for Simultaneous Determination of Polyphenolic Compounds in Medicinal Plants. Pharmacognosy Res. 2017;9(5):S67-73.

[66] Reich E, Widmer V. Plant Analysis 2008 - Planar Chromatography. Planta Med. 2009;75(07):711-8.

[67] Dalavi NB, Gawali VB. Comparative HPTLC Estimation and Antibacterial Effect of Ellagic acid, Gallic acid and Ethanolic Extract of Syzygium cumini seeds under accelerated Storage Condition. Int. J. Pharmacogn. Phytochem. Res. 2017;9(07):965-9.

[68] Bagul M, Srinivasa H, Padh H, Rajani M. A Rapid Densitometric Method for Simultaneous Quantification of Gallic acid and Ellagic acid in Herbal Raw Materials Using HPTLC. J Sep Sci. 2005;28(6):581-4.

[69] Syed Y, Khan M. Chromatographic Profiling of Ellagic acid in Woodfordia fruticosa Flowers and Their Gastroprotective Potential in Ethanol-Induced Ulcers in Rats. Pharmacognosy Res. 2016;8 Suppl 1:S1-11.

[70] Bazylko A, Tomczyk M, Flazińska A, Lęgas A. Chemical Fingerprint of Potentilla species by using HPTLC Method. J Planar Chromatogr Mod TLC. 2011;24(5):441-4.

[71] Riffault L, Destandau E, Pasquier L, André P, Elfakir C. Phytochemical Analysis of Rosa hybrida Cv. "Jardin de Granville” by HPTLC, HPLC-DAD and HPLC-ESIHRMS: Polyphenolic Fingerprints of Six Plant Organs. Phytochemistry. 2014;99:127-34.

[72] Tiwari P, Patel RK. Development and Validation of HPTLC Method for Quantification of Gallic acid and Ellagic acid in Ashwagandharishta. Asian J Res Chem. 2012;5(6):759-64.

[73] Jeganathan NS, Kannan K. HPTLC Method for Estimation of Ellagic acid and Gallic acid in Triphala Churanam Formulations. Res J Phytochem. 2009;2(1):1-9.
[74] Patel VR, Patel RK. HPTLC Method Development \& Validation for Quantification of Markers of Dhatrinisha Churna. Pharmacogn J. 2012;4(29):26-9.

[75] Preeti Tiwari and Rakesh K. Patel. Quantification of Gallic acid and Ellagic acid in Arjunarishta by validated HPTLC densitometry. Int J Pharm Sci Res. 2012;3(07):2215-23.

[76] Patel V, Patel R. Simultaneous Analysis and Quantification of Markers of Manjisthadi Churna Using High Performance Thin Layer Chromatography. Indian J Pharm Sci. 2013;75(1):106-9.

[77] Lozano-Sánchez J, Borrás-Linares I, Sass-Kiss A, SeguraCarretero A. Chromatographic Technique: High-Performance Liquid Chromatography (HPLC). Modern Techniques for Food Authentication. 2nd Ed. Da-Wen Sun Ed., Elsevier; 2018;459-526.

[78] Arapitsas P. Hydrolyzable Tannin Analysis in Food. Food Chem. 2012;135:1708-17.

[79] Dhanani T, Shah S, Kumar S. A Validated High-Performance Liquid Chromatography Method for Determination of TanninRelated Marker Constituents Gallic acid, Corilagin, Chebulagic acid, Ellagic acid and Chebulinic acid in Four Terminalia species from India. J Chromatogr Sci. 2015;53(4):625-32.

[80] Kadam PV, Yadav KN. C. L. B. and M. J. P. Development and validation of a HPLC analytical method for determination of Ellagic acid in Epilobium angustifolium extract. Int J Pharm Sci Res. 2019;10(3):1300-6.

[81] Assunção PI, da Conceição EC, Borges LL, de Paula JA. Development and Validation of a HPLC-UV Method for the Evaluation of Ellagic acid in Liquid Extracts of Eugenia uniflora L. (Myrtaceae) Leaves and Its Ultrasound-Assisted Extraction Optimization. Evidence-based Complement. Altern. Med. 2017;1-9.

[82] Owczarek A, Gudej J. Investigation into Biologically Active Constituents of Geum rivale L. Acta Pol. Pharm. Drug Res. 2013;70(1):111-4.

[83] Aguilera-Carbo AF, Augur C, Prado-Barragan LA, Aguilar CN, Favela-Torres E. Extraction and Analysis of Ellagic acid from Novel Complex Sources. Chem Pap. 2008;62(4):440-4.

[84] Chernonosov AA, Karpova EA, Lyakh EM. Identification of Phenolic Compounds in Myricariabracteata Leaves by High-Performance Liquid Chromatography with a Diode Array Detector and Liquid Chromatography with Tandem Mass Spectrometry. Brazilian J. Pharmacogn. 2017;27(5):576-9.

[85] Aybastıer Ö, Dawbaa S, Demir C. Investigation of Antioxidant Ability of Grape Seeds Extract to Prevent Oxidatively Induced DNA Damage by Gas Chromatography-Tandem Mass Spectrometry. J Chromatogr B Analyt Technol Biomed Life Sci. 2018;1072:328-35.

[86] Tavares IM, Lago-Vanzela ES, Rebello LP, Ramos AM, Gómez-Alonso S, García-Romero E, et al. Comprehensive Study of the Phenolic Composition of the Edible Parts of Jambolan Fruit (Syzygium cumini (L.) Skeels). Food Res Int. 2016;82:1-13.

[87] Iasnaia Maria de Carvalho Tavaresa. Tuany Yuri KuboyamaNogueiraa, M. A. M.; Sergio Gómez-Alonsob, Eleni Gomesa, Roberto Da-Silvaa, I. H.-G.; Lago-Vanzelaa, E. S. Dehydration of Jambolan [Syzygium cumini (L.)] Juice during Foam Mat Drying: Quantitative and Qualitative Changes of the Phenolic Compounds. Food Res Int. 2017;102:32-42.

[88] Tavares IM. C., Nogueira TY, Mauro MA, Gómez-Alonso S, Gomes E, Da-Silva R, et al. Corrigendum to "Dehydration 
of Jambolan [Syzygium cumini (L.)] Juice during Foam Mat Drying: Quantitative and Qualitative Changes of the Phenolic Compounds". Food Res Int. 2017;102:32-42.

[89] Peng S, Scalbert A, Monties B. Insoluble Ellagitannins in Castanea sativa and Quercus petraea Woods. Phytochemistry. 1991;30(3):775-8.

[90] Kumar Kammalla A, Kumar Ramasamy M, Aruna AG. D.; Kaliappan, I. Development and Validation of a RP-HPLC Method for the Simultaneous Determination of Mangiferin, Ellagic acid and Hydroxycitric acid in Polyherbal Formulation. Pharmacogn J. 2014;6(3):23-8.

[91] Bansal A, Chhabra V, Rawal RK, Sharma S. Chemometrics: A New Scenario in Herbal Drug Standardization. J Pharm Anal. 2014;4(4):223-33.

[92] Giri L, Andola HC, Kant Purohit V, Rawat MS, Rawal RS, Bhatt ID. Chromatographic and Spectral Fingerprinting Standardization of Traditional Medicines: An Overview as Modern Tools. Res J Phytochem. 2010;4(4):234-41.

[93] Stalikas CD. Extraction, Separation, and Detection Methods for Phenolic Acids and Flavonoids. J Sep Sci. 2007;30(18):3268-95.

[94] Zoechling A, Liebner F, Jungbauer A. Red Wine: A Source of Potent Ligands for Peroxisome Proliferator-Activated Receptor ү. Food Funct. 2011;2(1):28-38.

[95] Ghadage DM, Kshirsagar PR, Pai SR, Chavan JJ. Extraction Efficiency, Phytochemical Profiles and Antioxidative Properties of Different Parts of Saptarangi (Salacia chinensis
L.) - An Important Underutilized Plant. Biochem Biophys Rep. 2017;12:79-90.

[96] Hadrich F, Cher S, Gargouri YT, Adel S. Antioxidant and Lipase Inhibitory Activities and Essential Oil Composition of Pomegranate Peel Extracts. J Oleo Sci. 2014;63(5):515-25.

[97] Zehl M, Braunberger C, Conrad J, Crnogorac M, Krasteva S, Vogler B, et al. Identification and Quantification of Flavonoids and Ellagic acid Derivatives in Therapeutically Important Drosera Species by LC-DAD, LC-NMR, NMR, and LC-MS. Anal Bioanal Chem. 2011;400(8):2565-76.

[98] Lee JH, Johnson JV, Talcott ST. Identification of Ellagic acid Conjugates and Other Polyphenolics in Muscadine grapes by HPLC-ESI-MS. J Agric Food Chem. 2005;53(15):6003-10.

[99] Kumar S, Singh A, Kumar B. Identification and Characterization of Phenolics and Terpenoids from Ethanolic Extracts of Phyllanthus Species by HPLC-ESI-QTOF-MS/MS. J Pharm Anal. 2017;7(4):214-22.

[100] Costa EV, Lima DL, Evtyugin DV, Esteves VI. Development and Application of a Capillary Electrophoresis Method for the Determination of Ellagic acid in E. globulus Wood and in Filtrates from E. globulus Kraft Pulp. Wood Sci Technol. 2014;48(1):99-108.

[101] Snoussi A, Hayet BH, Essaidi I, Zgoulli S, Moncef CM, Thonart $\mathrm{P}$, et al. Improvement of the Composition of Tunisian Myrtle Berries (Myrtus communis L.) Alcohol Extracts. J Agric Food Chem. 2012;60(2):608-14. 